Олга Стојадиновић*

Универзитет у Београду

Филолошки факултет

Докторанткиња
371.3::811.134.2'243

https://doi.org/10.18485/zivjez.2020.40.1.12 Оригинални научни рад/ Стручни рад

\title{
ПОСЛЕДЊЕ РЕЧИ КЬИЖЕВНИХ ЛИКОВА (НА МАТЕРИЈАЛУ СТВАРАЛАШТВА АНТОНА ПАВЛОВИЧА ЧЕХОВА)
}

Рад се бави проучавањем последњих речи књижевних јунака на материјалу прича и драма Антона Павловича Чехова. Циљ рада је да понуди преглед говорне ситуације последњих речи фиктивних ликова на корпусу Чеховљевог стваралаштва уз њихову прагматичку анализу на основу теорије говорних чинова. Анализом прикупљеног материјала дошли смо до закључка да су у последњим речима књижевних ликова најзаступљенији директиви и експресиви, ређе асертиви и декларативи, док комисиви, због специфичности говорне ситуације, нису заступљени.

Кључне речи: последње речи књижевних јунака, Антон Павлович Чехов, руска књижевност, говорни чинови.

\section{1. Увод}

Предмет нашег рада представљају последње речи књижевних ликова, као интересантан феномен који писцу пружа могућност да у простору уметничке фикције самостално креира и читаоцу приближи и прикаже специфичну говорну ситуацију самртнога часа својих књижевних јунака, њихових последњих исказа, па и мисли. Инспирацију за истраживање оваквог типа нашли смо у раду проф. др академика Предрага Пипера, под називом Говорник као смртник и самртник (Пипер 2014: 457-472), у коме се проучава говорна ситуација самртнога часа и последњег обраћања самртника, али се даје

* oljastojadinovic9@gmail.com 
и наговештај да би се слично истраживање могло спровести на простору књижевних дела, чија би анализа била значајна „не само са становишта њихове психолошке уверљивости у структури дела и књижевних ликова у њему него и са становишта увида у личност писца, у његов стваралачки поступак и његов однос према властитом делу“ (Пипер 2014: 471).

Теорија говорних чинова првобитно је формулисана, разрађена и представљена од стране Џ. Л. Остина у оквиру његових предавања на Харварду, где је истакнуто да реченични искази не представљају пуки опис неке радње, већ „само исказивање да се нешто чини или пак тврђење да се то и то чини - значи то и то чинити" (Остин 1994: 16). Циљ нашег рада била је прагматичка анализа прикупљених примера помоћу теорије говорних чинова са циљем одређивања њихове заступљености у датој говорној ситуацији, као и презентација и интерпретација анализиране грађе ради сагледавања комплексне проблематике последњих речи и специфичности овакве говорне ситуације из њене фиктивне перспективе дате у књижевном стваралаштву. Такође, настојали смо и да одредимо како је писац представио своје књижевне ликове у говорној ситуацији самртног часа и да ли им је наменио комуникацијску улогу говорника у тим специфичним тренуцима или их је пак из одређених разлога лишио те улоге. С тим у вези покушали смо да дефинишемо „припремљеност” односно „неприпремљеност” књижевних ликова за коначни одлазак, њихов ниво „свести”, односно „несвести”, и „смирености”, односно „немира”. Приликом прагматичке анализе користили смо се типологијом комуникативних функција исказа понуђеној од стране Љ. Поповић, према којој су искази подељени на асертивне, директивне, интерогативне, комисивне, пермисивне, експресивне и декларативне (Пипер и сарадници 2005: 985-1059).

Анализирани корпус саставили смо проучавањем стваралаштва Антона Павловича Чехова, његових прича и драма, које смо изабрали због психолошки уверљивих и 
разноликих портрета књижевних јунака. Истраживање је обављено на корпусу састављеном од осам томова сабраних дела А. П. Чехова на руском језику, али смо приликом цитирања користили и позивали се и на електронска издања. За сваки оригиналан цитат на руском језику наведен је и превод на српски језик преузет из два тома изабраних Чеховљевих дела или преведен од стране аутора овог текста, уколико у парентези није наведено супротно.

\section{2. Анализа}

Последњу говорну ситуацију или говорну ситуацију самртног часа као неизбежни и саставни део људског живота, Чехов је више пута описивао у својим делима, а нека дела су и у потпуности била посвећена тематици смрти и последњих молби или жеља, попут прича као што су Н. М. Пржеваљски (H.M. Пржевальский) и Глумачка пропаст (Актерская гибель) у којима јунаци, предосећајући скори долазак смрти, експлицитно исказују жељу за местом последњег и вечног почивалишта. Кратак текст посвећен Николају М. Пржеваљском представља пишчево размишљање о последњој молби овог истакнутог руског географа, природњака и путописца, да буде сахрањен на обали језера Исик Кул ${ }^{1}$ (Чехов 1970в: 505) са закључком о исправности такве одлуке, иако не представља најлогичнији избор у сличним ситуацијама, попут жеље за повратком у отаџбину и родно место, каква је исказана у делу Глумачка пропаст (Актерская гибель), где главни јунак суочен с осећајем блиске смрти управо изражава жељу да се врати кући у родни

1 „На самрти Н.М. Пржеваљски затражио је да буде сахрањен на обали језера Исик-Кул. Бог је умирућем дао снагу да постигне још један подвиг - да потисне осећај чежње за родном земљом и да преда свој гроб пустињи.“ „Н. М. Пржевальский, умирая, просил, чтобы его похоронили на берегу озера Иссык-Куль. Умирающему бог дал силы совершить еще один подвиг - подавить в себе чувство тоски по родной земле и отдать свою могилу пустыне." (Чехов 1970в: 505) 
град² (Чехов 1970а: 217). Говорним чином директивне природе главни јунак приче саопштава последњу жељу да отпутује у Вјазму, изражену путем елиптичних конструкција и оптативно употребљеног потенцијала и императива, паралелно с осећајем експресивног кајања којим глумац констатује да је његов живот неповратно изгубљен: „В Вязьму надо! Ей-богу, в Вязьму! Ни жены, ни детей,- бормотал Щипцов.- Не идти бы в актёры, а в Вязьме жить! Пропала, Семён, жизнь! Ох, в Вязьму бы!"3 (Чехов 1970а: 220).

Кајање итугазбогосећајадајеживотпроживљен механички, без размишљања, и сасвим не онако како треба, честа је тема Чеховљевих прича. У делу Досадна прича (Скучная история), признати професор универзитета, Николај Степанович, тајни саветник и носилац многих одликовања, суочен са тешком болешћу почиње да преиспитује свој живот и животне одлуке, односе са другим људима, као и однос према свом позиву, науци, свету, али и према самом себи. Отуђен од породице, од жене и ћерке, Николај Степанович путује у Харков да тамо проведе последње дане. Осећајући потпуну равнодушност према свему што га окружује, главни јунак седи у хотелској соби и покушава да упозна самог себе и да дефинише своје жеље и пати јер увиђа одсуство нечег великог и главног, неке опште идеје која би његов живот учинила вредним и сврсисходним и дала му смисао и снагу да издржиу тешким тренуцима, да не клоне духом и не падне у малодушност, апатију и обузетост мрачним мислима и осећањима. Посебну резигнираност главни јунак осећа због тога што га ни славно име, ни блистава каријера, ни исправно проведен живот не могу спасити и заштити од страдања. С тим у вези, последње мисли главног јунака ове

2 „Морам ићи кући! ..У Вјазму ... у своју домовину... Тамо бих желео да умрем ... Ништа ме не боли, али... осећам ..."

„Домой надо!... В Вязьму... на родину... Там бы помереть... Ничего не болит, но я... чувствую..." (Чехов 1970а: 217)

3 „Морам у Вјазму! Богами, у Вјазму! Ни жене, ни деце, - мрмљао је Шипцов. - Није требало да идем у глумце, већ да живим у Вјазми! Изгубљен живот, Семјоне! Ох, кад бих могао у Вјазму!“ 
приче у ширем контексту представљају његова размишљања о животу, његову саморефлексију и вредновање проживљеног, док последње речи представљају његов опроштај од Каће, ћерке његовог покојног друга, очног лекара, коју му је пријатељ након своје смрти оставио на старање. Николај Степанович био је посебно везан за њу и његовим немим опроштајем од ње завршава се и прича о нашем јунаку.

Давай, Катя, завтракать, - говорю я, натянуто улыбаясь. - Будет плакать! И тотчас же я прибавляю упавшим голосом: Меня скоро не станет, Катя... Катя встает и, холодно улыбнувшись, не глядя на меня, протягивает мне руку. Мне хочется спросить: «Значит, на похоронах у меня не будешь?»... Черное платье в последний раз мелькнуло, затихли шаги... Прощай, мое сокровище!4 (Чехов 1970в: 333-334)

С друге стране, у причи Архијереј, главни јунак своју позицију у друштву види као терет, о чему сведоче његове последње речи у облику реторичког питања које преосвећени Петар у поверењу упућује оцу Сисоју вече пре него што ће умрети: „Какой я архиерей? - продолжал тихо преосвященный. - Мне бы быть деревенским священником, дьячком... или простым монахом... Меня давит всё это... давит..." (Чехов 1899-1902: Web) ${ }^{5}$.

Неочекивана болест и брзина последњег часа лишила је главног јунака могућности последњег говора, али писац читаоца оставља у уверењу да јунак поздравља блиску смрт као ослобођење и почетак новог живота коме се радује: „Как хорошо! - думал он. - Как хорошо!”' (Чехов 1899-1902: Web).

4 „Хајде, Катја, да доручкујемо, - кажем смејући се усиљено. - Биће времена за плакање! И одмах додајем тихим гласом: Ускоро ме више неће бити, Катја ... Катја устаје и, осмехнувши се хладно, пружа ми руку, не гледајући ме. Хтео бих да је упитам: „Дакле, нећеш бити на мојој сахрани?“ ... Црна хаљина је промакла последњи пут, кораци су утихнули ... Збогом, злато моје!“

5 „Какав сам ја архијереј? Требало би да будем сеоски поп, црквењак... или обичан калуђер... Мене гуши све ово... гуши..." (Чехов 2013а: 676)

6 „Како је лепо! - мислио је, - Како је лепо!“ (Чехов 2013а: 676) 
А он уже не мог выговорить ни слова, ничего не понимал, и представлялось ему, что он, уже простой, обыкновенный человек, идет по полю быстро, весело, постукивая палочкой, а над ним широкое небо, залитое солнцем, и он свободен теперь, как птица, может идти, куда угодно!" (Чехов 1899-1902: Web)

Као што се може видети, Чеховљеви књижевни јунаци јединствену ситуацију последњих речи у тренутку самртнога часа доживљавају и проживљавају на различите начине: од спремности,прибраностиипомиреностисасудбиномдопотпуне неприпремљености за коначни одлазак и неочекиваности последњег трена, што диктира и њихову реакцију и последње саопштене или несаопштене речи. Занимљив аспекат који се на материјалу књижевних дела може проучавати, за разлику од стварности, представља поље последњих мисли које јунаци имају и које неретко садрже најинтензивније и најсадржајније поруке које књижевни јунаци из различитих разлога не изговарају или пак не успевају да изговоре. Такође, у одређеним случајевима, тешко је поставити границу између последњих мисли и последњих речи, јер се оне често поклапају, допуњују и међусобно надовезују или објашњавају.

У причи Павиљон бр. 6 доктор Андреј Јефимич Рагин умире од можданог удара изазваног Никитиним ударцима, неправедно затворен у павиљону као душевно оболео човек. Његове последње речи заправо представљају последње свесно и намерно изабрано ћутање о чему нас писац обавештава пратећи ток јунакових мисли: „Он не ел, не пил, лежал неподвижно и молчал. «Мне всё равно, - думал он, когда ему задавали вопросы. - Отвечать не стану... Мне всё равно"8 (Чехов 1892: Web).

7 „А он више није могао да изговори ни реч, ништа није схватао, и чинило му се како, већ као сасвим једноставан, обичан човек, иде пољем брзо, весело, лупкајући штапићем, а над њим је широко небо, преплављено сунцем, и он је сада слободан као птица, може да иде куда му се прохте!“ (Чехов 2013а: 676-677)

8 „Није јео, није пио, лежао је непомично и ћутао. „Мени је свеједно мислио је кад су му постављали питања. - Нећу да одговарам... Свеједно ми је." (Чехов 2013а: 427). 
Ћутање изнуђено болешћу и слабошћу описано је у причи Туга (Горе), где се ћутња старице контрастира непрекидној и неповезаној причи њеног мужа, Григорија Петрова, који је вози код лекара. Старица умире без речи на путу за болницу и писац бележи само израз њеног лица који се пред смрт битно разликовао од обичног свакодневног израза који је имала.

Когда вчера вечером воротился он домой, по обыкновению пьяненьким, и по застарелой привычке начал браниться и махать кулаками, старуха взглянула на своего буяна так, как раньше никогда не глядела. Обыкновенно выражение ее старческих глаз было мученическое, кроткое, как у собак, которых много бьют и плохо кормят, теперь же она глядела сурово и неподвижно, как глядят святые на иконах или умирающие. ${ }^{9}$ (Чехов 1970а: 153).

Сличан књижевни поступак као у причи Туга, где смрт долази ономе ко умире као спас од лошег живота, а уједно и као казна и освета блиским људима због њиховог непримереног понашања и нељубави, уочљив је и у причи Ветропирка (Попрыгунья), где главна јунакиња, која се лоше односила према свом мужу, бива кажњена његовом изненадном смрћу. Лекар Осип Степанич Димов умире од дифтерије, без последњих речи и у бунилу, а његове последње исказане речи у причи представљају говорни чин директивне природе у виду упутства жени: „Мама, ты не входи ко мне, а только подойди к двери. - Вот что... Третьего дня я заразился в больнице дифтеритом, и теперь... мне нехорошо. Пошли поскорее за Коростелевым"10(Чехов 1891: Web).

9 „Кад се синоћ вратио кући, пијан као и обично, и по старој навици почео да псује и маше песницама, старица је погледала свог галамџију онако како га никада раније није гледала. Уобичајен израз њених старачких очију био је мученички, кротак, као код паса које много бију и лоше хране, али сада је гледала строго и непомично, као што гледају свеци на иконама или они који умиру.“

10 „Мамице, не улази код мене, него само приђи до врата. Ево шта је. Прекјуче, у болници, заразио сам се дифтеријом, и сада... Нисам добро. Пошаљи одмах по Коростељева." (Чехов 2013a: 368). 
О неочекиваности последњег часа и неприпремљености за коначни одлазак говори и тужна прича под називом Сељаци (Мужики), где је описана смрт Николаја Чикилдејева, слуге у московском хотелу „Словенски базар“, који се разболео, добио отказ на послу и потрошио сав новац на лечење, услед чега је одлучио да се са женом и ћерком врати кући у село, како би тамо оздравио и опоравио се окружен вољеним, блиским људима. Међутим, на селу га је неочекивано дочекала огромна породица која је живела у тешкој немаштини, и којима је стога он, болестан и без новца, представљао само терет.

Николай стал дрожать; лицо у него осунулось и, как говорили бабы, сжалось в кулачок; пальцы посинели. Он кутался и в одеяло, и в тулуп, но становилось все холоднее. К вечеру он затосковал; просил, чтобы его положили на пол, просил, чтобы портной не курил, потом затих под тулупом и к утру умер. ${ }^{11}$ (Чехов 1897: Web)

Услед незнања и немаштине, лечио га је нестручан лекар, или како га зову у причи - Шарлатан, који је уместо да помогне само погоршао болесниково стање и проузроковао превремену смрт. Овај мотив надрилекара, варалице, човека који се лажно представља као лекар, а лечећи људе заправо их убија, представља лутајући мотив присутан како у причи Актерская гибель, тако и у причи Хитна помоћ (Скорая помощь), где људи покушавају да помогну дављенику извученом из воде, а заправо га из незнања убијају. Његове последње речи окупљен народ доживљава као бунцање, а оне изражавају снажну експресивну љутњу и негодовање уз исказе непристајања и одбијања, који су упућени некоме ко није присутан.

Заместо, говорит, родителя... Ах, волк те заешь! Это за семь-то рублев?... Тот бессмысленно поводит глазами и

11 „Николај поче да се тресе, лице му се смежура и, што би жене рекле, претвори се у песницу; помодреше му и прсти. Умотавао се и у јорган и у кожух, али му је било све хладније. Сневесели се у сумрак; замоли да га пренесу на патос, да кројач не пуши, па се умири испод кожуха и у свитање испусти душу.“ (Чехов 2013а: 564-565) 
молчит... Это за семь-то рублей? - бормочет утопленник.

- Поди ты, говорю, к псу... Мы не желаем... (Чехов 1970б: 304), Поди ты, говорю, к псу, - бормочет утопленник, не сопротивляясь и как бы не замечая, что его поднимают и кладут на рогожу. - Мы не желаем. ${ }^{12}$ (Чехов 1970б: 305).

И док једни, попут Ивана Дмитровича Червјакова из приче Чиновникова смрт (Смерть чиновника) умиру без речи тако што просто оду кући, легну на диван и умру, паралисани осећајем ужасног страха и инфериорности пред људима који поседују виши чин, други попут Беликова, наставника грчког, из приче Човек у футроли (Человек в футляре), умиру у тишини из осећаја бескрајне осрамоћености и увређености која се не може преживети и опростити.

И этим раскатистым, заливчатым «ха-ха-ха» завершилось всё: и сватовство, и земное существование Беликова... Он лежал под пологом, укрытый одеялом, и молчал; спросишь его, а он только да или нет - и больше ни звука... Через месяц Беликов умер. ${ }^{13}$ (Чехов 1898a: Web).

Занимљив је случај који је писац навео у својој причи Огрозд (Крыжовник), а који представља пример последњег геста: „Деньги, как водка, делают человека чудаком. У нас в городе умирал купец. Перед смертью приказал подать себе тарелку меду и съел все свои деньги и выигрышные билеты вместе с медом, чтобы никому не досталось"14 (Чехов 1898б: Web).

12 „Каже, уместо родитеља ... Ах, ђаво те однео! Је ли то за седам рубаља? ... Овај бесмислено гледа око себе и ћути ... Је ли то за седам рубаља? мрмља дављеник. - Кажем, иди дођавола... Не желимо ..., Кажем, иди дођавола, - мрмља дављеник, не противећи се, као да не примећује да га подижу и стављају на рогожину. - Не желимо.“

13 „И тим бучним испрекиданим „ха-ха-ха» завршило се све: и просидба, и Беликовљево земаљско битисање... Лежао је иза завесе, покривен ћебетом, и ћутао; питаш га нешто, а он само „да» или „не» - и више ни гласка... После месец дана Беликов је умро.“ (Чехов 2013а: 613).

14 „Новац, као вотка, човека учини настраним. Код нас у граду био на самрти трговац. Пре него што ће да умре, он нареди да му донесу тацну меда, и с медом поједе сав свој новац и лозове, како његово богатство не би припало другом.“ (Чехов 2013а: 620). 
И док један од војника из приче Гусев неочекивано умире док је играо карте, неспреман и у бунилу, изговарајући само „Я сейчас, братцы..." ${ }^{15}$ (Чехов 1970в: 356), главни јунак ове приче умире свестан скорог краја и тужан јер неће дочекати да види земљу и да брод дође до копна. На питање морнара и војника „A помирать страшно?“16, он одговара следећим речима које уједно представљају и његове последње речи којима исказује забринутост због ближњих које оставља на милост и немилост судбини и последњу жељу за сном:

Страшно. Мне хозяйства жалко. Брат у меня дома, знаешь, не степенный: пьяница, бабу зря бьет, родителей не почитает. Без меня всё пропадет и отец со старухой, гляди, по миру пойдут. Одначе, брат, ноги у меня не стоят, да и душно тут... Пойдем спать. ${ }^{17}$ (Чехов 1970в: 361-362)

Помиреност са доласком смрти видљива је и у причи Хоћу да спавам (Cnamь хочеться), где Јефим док га доктор прегледа, сталожено одговара доктору да му је дошао крај исказима са асертивном функцијом у облику најаве блиске смрти и констатације „коли смерть пришла, что уж тут“" ${ }^{18}$, као и експресивом који изражава захвалност доктору за труд.

Помирать, ваше благородие, пришло время... Не быть мне в живых... // Полно вздор говорить... Вылечим! // Это как вам угодно, ваше благородие, благодарим покорно, а только мы понимаем... Коли смерть пришла, что уж тут. ${ }^{19}$ (Чехов 1970в: 69)

15 „Сад ћу, браћо... “

16 „Да ли се плашиш смрти?“

17 „Плашим се. Жао ми је домаћинства. Брат код куће ми је неозбиљан: пијаница, туче жену без разлога, не поштује родитеље. Без мене све ће пропасти и, гле, отац са старицом поћи ће по свету. Међутим, брате, ноге ме издају, а овде је и загушљиво ... Хајдемо на спавање.“

18 „Ако је смрт дошла, шта да се ту ради.“

19 „Ваша милости, дошло је време да се умре... Нећу остати жив... // Не причај свашта ... Излечићемо те! // Како год вам драго, ваша милости, понизно вам се захваљујемо, али само ми разумемо ... Ако је смрт дошла, шта да се ту ради. " 
Међу јунацима Чеховљевих прича постоје и они који призивају сопствену смрт, попут Васе из приче Жене (Бабы), који се обраћа Богу с молбом да му пошаље смрт: „Вася сидит в другой комнате, держится за голову и плачет: „Злодей я! Погубил я свою жизнь! Пошли мне, господи, смерть!» На другой день Вася заболел, вроде как бы холерой, и к вечеру, слышу, помер"20 (Чехов 1970в: 370).

Његова жена Машењка, која после смрти мужа бива осуђена и затворена, умире на путу за Сибир од грознице. Писац не дели са читаоцем њене последње речи, већ само кроз лик Матвеја Савича, локалног Тартифа, констатује њену смрт као заслужену и неминовну казну за лакомисленост и непослушност. Па ипак њене последње речи у причи, као последње речи у ширем смислу, упућене су управо М. Савичу, приликом његових долазака у затвор како би је посетио, и представљају њено одбијање и страх да прича са човеком који јој је проузроковао несрећу, кроз говорни чин директивне природе у форми императива „Уйди“21: „А она, бывало, увидит меня и начнет трястись всем телом, машет руками и бормочет: 'Уйди! Уйди!' И Кузьку к себе прижимает, словно боится, чтоб я не отнял"22 (Чехов 1970в: 371).

Занимљиве су и приче у којима јунаци услед тренутне слабости или из освете размишљају о сопственој смрти и разрађују у глави сценарио таквог догађаја, попут Лизочке Кудринске из приче Мученици (Страдальцы), која се прехладила и добила грчеве због чега је умислила да је смртно болесна и почела да фантазира о смрти ${ }^{23}$ и о томе како би

20 „Васја седи у другој соби, држи се за главу и плаче: „Ја сам злотвор! Уништио сам свој живот! Пошаљи ми, Господе, смрт! “Следећег дана Васја се разболео, као од колере, а увече је, чујем, умро.“

21 „одлази!“

22 „И дешавало се да ме види и да почне да дрхти целим телом, маше рукама и мрмља:„ Одлази! Одлази! “ И прибија Кузку уз себе, као да се плаши да ћу да га отмем.“

23 Забринутом мужу Лизочка упућује следеће речи: „За себя я не боюсь... мне всё равно, даже я рада умереть, но мне тебя жаль! Вдруг ты овдовеешь и останешься один... Что ж? Поплачешь, погорюешь, а потом и привыкнешь. Даже женишься" (Чехов 1970а: 405-406). 
то изгледало када би свима на самртном одру шапутала последње „прости” 24 (збогом). Или, попут Петра из приче Тешки људи (Тяжелые люди) који после свађе са родитељима бежи из куће и размишља о сопственој смрти која ће се десити без последњих речи, али ће се зато појавити у свим новинама и бити највећа казна његовом оцу.

Где-нибудь под Курском или под Серпуховом он, обессиленный и умирающий от голода, свалится и умрет. Его труп найдут, и во всех газетах появится известие, что там-то студент такой-то умер от голода... ${ }^{25}$ (Чехов 1970б: 29)

Самоубиства у Чеховљевим причама и драмама углавном су мотивисана жељом за осветом особи која им је нанела бол, тугом због неузвраћене љубави, жељом да се оконча живот који им није донео ништа добро или, пак, услед немогућности проналаска смисла сопственог живота. Драма Иванов завршава се самоубиством главног лика, који говорним чином директивне природе наређује присутним људима да се склоне и да га оставе на миру, како би спровео своје мисли о самоубиству у дело.

Постой, я сейчас все это кончу! Проснулась во мне молодость, заговорил прежний Иванов! (Вынимает револьвер.)... Долго

„За себе се не плашим... свеједно ми је, чак сам и рада умрети, али ми је тебе жао! Одједном ћеш постати удовац и остати сам... Шта да се ради? Мало ћеш плакати, туговати, а затим ћеш се и навићи. Чак ћеш се и оженити.“

24 „И Лизочка рисует себе картину собственной смерти, как вокруг ее смертного одра теснятся мать, муж, кузина Варя с мужем, родня, поклонники ее 'таланта', как она шепчет последнее 'прости'.” (Чехов 1970а: 406).

„И Лизочка себи црта слику сопствене смрти, како су се око њеног самртног одра збили мајка, муж, рођака Варја са мужем, родбина и поштоваоци њеног 〈>талента» и како она шапуће последње 'збогом'.“

25 „Негде у близини Курска или Серпухова, исцрпљен и мртав гладан, срушиће се и умрети. Пронаћи ће његов леш и у свим новинама појавиће се вест да је ту и ту студент тај и тај умро од глади.“ 
катил вниз по наклону, теперь стой! Пора и честь знать! Отойдите! Спасибо, Саша!... Оставьте меня! (Отбегает в сторону и застреливается.) ${ }^{26}$ (Чехов 1887: Web)

Поред прохибитивних исказа са директивном функцијом који имају јак илокутивни напон, јер говорник у руци држи револвер и наређује окупљеним људима да се склоне и оставе га на миру, присутни су и искази с експресивном функцијом где се говорник захваљује Саши и емотивно наглас размишља о свом животу. У драми Галеб (Чайка), Константин Гаврилович Трепљев убија се због неузвраћене љубави и осећаја „промашеног живота”. Последње речи, пре него што поцепа своје рукописе и изврши самоубиство, он упућује Нини, жени коју воли, а која несрећно воли другог мушкарца. Његове последње речи у ширем смислу представљају израз његове саморефлексије и потпуног очаја: „Вы нашли свою дорогу, вы знаете, куда идете, а я все еще ношусь в хаосе грез и образов, не зная, для чего и кому это нужно. Я не верую и не знаю, в чем мое призвание"27 (Чехов 1895: Web).

У причи под називом Волођа (Володя), о седамнаестогодишњем младићу који извршава самоубиство, Чехов покушава да проникне у психологију младих самоубица и објасни мотиве и разлоге који их подстичу на тако трагичне одлуке. Писац нам нуди опис младића који расте без оца, психички крхког, физички слабашног и друштвено не нарочито прилагођеног, који има изузетно лош однос са мајком и коме је стога тешко да у свету који га окружује пронађе чврсто упориште, мир, срећу и смисао, а његово постојеће нестабилно стање додатно се погоршава после првог

26 „Стани, ја ћу сад све то да окончам! Пробудила се у мени младост, проговорио је некадашњи Иванов! (вади револвер)... Дуго сам падао све ниже и ниже, сад стој! Време је да се стави тачка! Склоните се! Хвала ти, Саша!... Оставите ме! (Јурне у страну и убија се.)“ (Чехов 2013б: 118)

27 „Ви сте нашли свој пут, ви знате куда идете, а ја још тумарам у хаосу снова и слика и не знам коме и зашто све то треба. Ја не верујем и не знам у чему је мој позив." (Чехов 2013б: 169) 
љубавног искуства које главног јунака оставља разочараног и оптерећеног осећањима гриже савести због пропуштеног испита и могућег избацивања из школе. Притиснут тешким и нејасним непријатним осећањима каква раније није имао, младићево незадовољство достиже своју кулминацију. Он тешким речима и увредама напада мајку, говори јој да је не воли, да је се стиди и да у њеним речима и понашању види само лаж ${ }^{28}$. Његова последња мисао пред самоубиство била је у форми реторичког питања „Куда уйти?”29. Поред јунакових исказа са директивном функцијом, попут оног у виду забране „Не смейте носить этого ватерпруфа!“"30 (Чехов 1970б: 278),у његовим последњим речима које саопштава мајци, присутни су и многобројни експресиви који исказују говорникове снажне емоције љутње, беса и негодовања: „Maman, это неправда! сказал раздраженно Володя. - Зачем лгать? - Вы лжете! Для чего вы рассказываете про генералов и баронесс? Всё это ложь!..." ${ }^{31}$ (Чехов 1970б: 280).

Да самоубиство може бити извршено и у стању потпуне смирености и хладнокрвности, а не само у стању афекта,

28 „Зачем вы пудритесь? Это не пристало в ваши годы! Вы наводите на себя красоту, не платите проигрыша, курите чужой табак... противно! Я вас не люблю... не люблю!... Не люблю... не люблю! — продолжал он, задыхаясь. - Вы безнравственная, бездушная... Не смейте носить этого ватерпруфа! Слышите? А то я изорву его в клочки... А где состояние моего отца? Где ваши деньги? Вы всё промотали! Мне не стыдно своей бедности, но стыдно, что у меня такая мать... Когда мои товарищи спрашивают о вас, я всегда краснею...“ (Чехов 1970б: 278).

„Зашто стављате пудер? То не одговара вашим годинама! Улепшавате ce, не плаћате кад изгубите, пушите туђи дуван ... то је одвратно! Не волим вас ... не волим! ... не волим ... не волим! - настављао је губећи дах. - Неморални сте, бездушни ... Престаните да носите тај мантил! Да ли ме чујете? У супротном, поцепаћу га на комаде ... Где је имовина мога оца? Где је ваш новац? Све сте проћердали! Не стидим се свог сиромаштва, али се стидим што имам такву мајку ... Кад ме другови питају за вас, увек се зацрвеним..."

29 „Куда отићи?“

30 „Престаните да носите тај мантил!“

31 „Мама, то није истина! - рекао је љутито Волођа. - Зашто лажете? - Ви лажете! Зашто причате о генералима и бароницама? Све је то лаж!“ 
показује следећа Чеховљева прича под називом Иследник (Следователь), у којој жена решава да се убије након порођаја како би се осветила мужу за неверство и зато свима у својој околини почиње да прича како ће умрети чим се породи. ${ }^{32}$ Целокупна прича испричана је из перспективе њеног мужа, који је женине речи о предстојећој смрти испрва сматрао за сујеверје, бесмислицу и фикс-идеју ${ }^{33}$, да би након њене смрти поверовао да је у питању било необјашњиво предсказање. Описујући лекару догађаје који су претходили њеној смрти и последње речи своје жене, он бива поражен констатацијом његовог саговорника о женином планираном самоубиству тровањем, које је у причи исказано на следећи начин: „Но вот наступили и роды... Когда все кончилось, роженица пожелала взглянуть на младенца. Поглядела и сказала: - Ну, а теперь и умереть можно. Простилась, закрыла глаза и через полчаса отдала богу душу“34 (Чехов 1970б: 266).

Последње супругине речи „Ну, а теперь и умереть можно“35 (Чехов 1970б: 266) могле би спадати у исказе са пермисивном функцијом, с обзиром на то да овим речима она самој себи

32 „Делай, как знаешь, мне теперь все равно. К лету я буду уже на кладбище... Я нисколько не шучу, - говорит она. - Объявляю серьезно, что я скоро умру... Сейчас же после родов. Рожу и умру.“ (Чехов 1970б: 265)

„Ради шта хоћеш, мени је сад свеједно. До лета већ ћу бити на гробљу. Ни најмање се не шалим - говори она. - Озбиљно изјављујем да ћу ускоро умрети... Одмах после порођаја. Родићу и умрећу.“

33 „Близкая смерть стала ideefixe жены. Когда муж не слушал ее, она шла в кухню и говорила там о своей смерти с няней и кухаркой: Не много еще мне осталось жить, нянюшка. Как только рожу, сейчас же и умру. Не хотелось бы умирать так рано, да уж знать судьба моя такая“ (Чехов 1970б: 265).

„Блиска смрт постала је женина фикс-идеја. Када је муж није слушао, одлазила би у кухињу и тамо причала о својој смрти са дадиљом и куварицом: Нећу живети још дуго, дадиљице. Умрећу одмах након порођаја. Не умире ми се тако рано, али шта ћу када ми је таква судбина."

34 „А онда је дошао и порођај... Када је све било готово, породиља је пожелела да баци поглед на бебу. Погледала је и рекла: - А сада могу и да умрем. Поздравила се, затворила очи и кроз пола сата предала Богу душу.“

35 „А сад могу и да умрем.“ 
даје дозволу да изврши самоубиство или, пак, у исказе са декларативном функцијом у виду констатације и пресуде самој себи.

Постоје међу Чеховљевим јунацима и они који се у тешким и последњим тренуцима обраћају вољеним и блиским особама. Неки то, попут Александра Тимофејича, јунака приче Вереница (Невеста), због географске удаљености чине путем последњег писма, које представља уједно и његове последње речи у ширем смислу, с обзиром на то да је писмо послао непосредно пред смрт: „Пришло из Саратова письмо от Саши. Своим веселым, танцующим почерком он писал, что путешествие по Волге ему удалось вполне, но что в Саратове он прихворнул немного, потерял голос и уже две недели лежит в больнице“36 (Чехов 1902-1903: Web).

Други добијају непријатно писмо и последње речи упућују особи која је далеко од њих, попут магистра Андреја Васиљевича Коврина, главног јунака приче Црни монах (Черный монах), који пред смрт дозива своју бившу жену Тању, којој је причинио много боли и која га у свом писму отворено криви за своју несрећу и смрт оца.

Он хотел позвать Варвару Николаевну, которая спала за ширмами, сделал усилие и проговорил:

— Таня!

Он упал на пол и, поднимаясь на руки, опять позвал:

- Таня!

Он звал Таню, звал большой сад с роскошными цветами, обрызганными росой, звал парк, сосны с мохнатыми корнями, ржаное поле, свою чудесную науку, свою молодость, смелость, радость, звал жизнь, которая была так прекрасна. Он видел на полу около своего лица большую лужу крови и не мог уже от слабости выговорить

36 „Стигло је из Саратова писмо од Саше. Својим веселим, несташним рукописом он је писао да му је путовање по Волги потпуно успело, али да је у Саратову мало оболео, изгубио глас и већ две недеље лежи у болници." (Чехов 2013а: 694) 
ни одного слова, но невыразимое, безграничное счастье наполняло все его существо. ${ }^{37}$ (Чехов 1893: Web)

Ипак најемотивнији од свих опроштаја представља опроштај барона Николаја Љвовича Тузенбаха од веренице Ирине. Овај књижевни лик из драме Три сестре (Три сестры) бива убијен на двобоју од стране капетана Василија Васиљевича Сољонија. Пре него што ће поћи на двобој, он се опрашта од веренице уверен да ће преживети и да ће кроз сат времена њих двоје опет бити заједно ${ }^{38}$, али након њене изјаве да га не воли, он губи полетност и само тужно констатује да је време да пође и последње збогом упућује вољеној жени уз уверење да се живот не завршава смрћу или да смрт заправо не постоји: „Надо идти, уже пора... Вот дерево засохло, но все

37 „Хтео је да зовне Варвару Николајевну, која је спавала иза паравана, напрегао се и изговорио:

- Тања!

Пао је на патос и, подижући се на руке, опет зовнуо:

- Тања!

Дозивао је Тању,звао јевеликубаштупунураскошногцвећапошкропљеног росом, дозивао је парк, борове чупавог корења, њиву ражи, своју чаробну науку, своју младост, смелост, радост, дозивао је живот који је био тако диван. На патосу, поред свог лица, угледао је велику локву крви и од немоћи није могао изговорити ни реч, али неизрецива, бескрајна срећа плавила је цело његово биће." (Чехов 2013а: 481)

38 „Тузенбах: Через час я вернусь и опять буду с тобой. (Целует ей руки.) Ненаглядная моя... (Всматривается ей в лицо.) Уже пять лет прошло, как я люблю тебя, и все не могу привыкнуть, и ты кажешься мне все прекраснее. Какие прелестные, чудные волосы! Какие глаза! Я увезу тебя завтра, мы будем работать, будем богаты, мечты мои оживут. Ты будешь счастлива. Только вот одно, только одно: ты меня не любишь!Ирина. Это не в моей власти! Я буду твоей женой, и верной, и покорной, но любви нет, что же делать!“ (Чехов 1900: Web)

„Тузенбах: Враћам се за сат и опет ћу бити с тобом. (Љуби јој руке.) Предивна моја... (Загледа јој се у лице.) Већ има пет година откако те волим, и још увек не могу да се навикнем, и ти ми изгледаш све лепша. Каква прелепа, дивна коса! Какве очи! Сутра ћу те одвести, ми ћемо радити, бити богати, снови моји ће оживети. Ти ћеш бити срећна. Само има једна ствар, само једна ствар: Ти мене не волиш!

Ирина: Ја ту не могу ништа! Бићу ти жена, и верна, и покорна, али љубави нема, тако је то!“ (Чехов 2013б: 271) 
же оно вместе с другими качается от ветра. Так, мне кажется, если я и умру, то все же буду участвовать в жизни так или иначе. Прощай, моя милая..."39 (Чехов 1900: Web).

\section{3. Закључци}

Резултати анализираног материјала показали су да већина јунака одлази неспремна, понекад и несвесна, у бунилу изговарајући последње речи или одлазећи без последњег говора, понекад из немоћи или услед неочекиваности последњег тренутка, а понекад у виду намерног ћутања и одбијања да се нешто каже или одговори на постављена питања. Одређени јунаци који су свесни скорог краја користе последње тренутке да се опросте од вољених људи, иако немају ту могућност, па неки ликови пред сам крај пишу писма далеким блиским особама или дозивају њихова имена. Са друге стране, постоје и они који смрт прижељкују, маштају о њој, дозивају је или помоћу смрти настоје да реше своје земаљске муке, освете се људима који су их повредили или побегну од живота. Ако претпоставимо да избор последњих речи пре свега једногласно показује шта је одређеној особи најдраже на свету и шта сматра за највећу животну вредност, могли бисмо навести и занимљив пример који сам писац у једној од прича наводи као случај настраности кроз анегдоту о богатом трговцу који пред смрт тражи да му се донесу мед и новац, како би их појео и на тај начин сачувао богатство за себе.

Такође, када је реч о реализацији говорних чинова, резултати анализе прикупљеног материјала недвосмислено показују да последње речи књижевни ликови остварују пре свега кроз употребу директива и експресива, ређе асертива и декларатива, док комисиви нису заступљени, што и не чуди с обзиром на специфичност говорне ситуације. На материјалу

39 „Треба да идем, време је... Ево, дрво се осушило, али се и даље повија на ветру. Тако се и мени чини, ако и умрем, ипак ћу учествовати у животу овако или онако. Збогом, мила моја..." (Чехов 2013б: 272) 
смо потврдили да се говорни чин директивне природе обично изражава путем императива или оптативно употребљеног императива или потенцијала и да се одликује употребом елиптичних реченица. Форму последњих речи књижевних јунака у већини случаја одликује краткоћа, вероватно због пишчеве намере да његова дела буду што експресивнија, аутентичнија и реалистичнија, односно, што ближа стварности, у којој често говорници у свом последњем „говору” из различитих разлога не успевају да кажу све што желе или да се изразе на најбољи могући начин. Као што смо навели, после директива, најзаступљенији су експресиви који лексички и интонацијски исказују различите емоције говорника: тугу, очај, бес, негодовање, неслагање, захвалност, извињење, итд.

На основу анализираног материјала и прикупљених резултата могли бисмо закључити да је писац психолошки уверљиво представио своје јунаке, углавном им додељујући комуникацијскуулогуговорника утим специфичним тренуцима, док ситуације у којима то није био случај указују на постојање концептуално дубље сврсисходности и оправданости таквог пишчевог опредељења које је углавном у спрези са психолошком елаборацијом појединачног књижевног лика и пишчевим виђењем уникалности саме ситуације у склопу одређеног књижевног дела. Након добијених резултата спроведене анализе дошли смо до закључкада у оним случајевима када је књижевним ликовима додељена улога говорника, већинањих својим последњим речима исказује последњу молбу, жељу, наредбу, заповест, поздравља се са блиским људима, изјављује им љубав, изговара или дозива најзначајнија имена, исказује бригу за оне који остају, вреднује проживљени живот, констатује или најављује блиску смрт, износи различите тврдње или се, пак, каје због нечега. Постоје и они који у последњим тренуцима постају равнодушни према спољашњем свету и своју равнодушност или резигнираност исказују кроз ћутање, чиме се оправдава пишчево опредељење да одређене књижевне ликове лиши потребе за исказивањем „последњих речи” и преузимања на себе говорничке функције. Они који у последњим моментима 
врше саморефлексију и размишљају о проживљеном животу или пак покушавају да побегну и ослободе се живота и земаљских мука, често постављају реторичка питања. Иако су прохибитиви у таквим ситуацијама ретки, наишли смо на један пример где самоубица својим претпоследњим речима управо изриче присутнима забрану приласка. Прагматичка анализа последњих речи књижевних јунака наводи на закључак о корелацији између специфичности дате говорне ситуације и реализације одређених говорних чинова који највише одговарају датој говорној ситуацији, што се у оквиру нашег истраживања може свести на истицање директива и експресива као најчешће коришћених и ситуацији најпримеренијих говорних чинова, и декларисање комисива као говорног чина који је најмање у складу са самом ситуацијом што је потврђено недостатком примера употребе комисива приликом вербализације последњих речи у оквиру ексцерпиране грађе.

Неприпремљеност књижевних јунака за „коначни одлазак”, њихов немир и њихово несхватање позиције у којој се налазе, у односу на јунаке који су спремни и који свесно и смирено реагују, упућује на пишчеву интенцију да што реалистичније и објективније представи сам чин „последњег тренутка”, о чему сведочи и закључак до којег је П. Пипер дошао у свом истраживању о томе да „већина људи одлази са овога светабез припремљеног последњег „говора” (Пипер 2014: 463). Припремљеност или неприпремљеност књижевних јунака за напуштање сцене књижевног дела писац конципира тако да се може уочити узрочно-последична веза између могућности сагледавања специфичности саме говорне ситуације таквог тренутка и решености књижевних јунака да артикулишу и вербализују своје последње мисли и жеље на одређен начин или, пак, да их прећуте и не искажу. Поред ћутања, које такође може бити вишезначно, можемо закључити да и претпоследње речи, као и последње мисли и дела књижевних ликова, могу носити велике и важне поруке, које писац често обликује као садржајније, па можда чак и значајније од званично последњих речијунака својих књижевних дела. 
Иако се простор књижевне фикције не може поистоветити са стварним светом и суштински се од њега разликује, поље књижевности свакако представља плодно тле за слична истраживања и сам рад би могао бити подстицајан за исцрпнија проучавања дате проблематике у оквиру дела других књижевних стваралаца, а анализа психолошке мотивисаности одређених ситуацијскихрешења или одређених речи ипоступакакњижевних ликова у Чеховљевим причама могла би представљати користан материјал приликом анализе поетике овог писца.

\section{ЛИТЕРАТУРА}

\section{Корпус}

Чехов 1887: А. П. Чехов, Иванов, [https://ilibrary.ru/text/964/p.4/index.html] Чехов 1891: А. П. Чехов, Попрыгунья, [https://ilibrary.ru/text/706/p.7/ index.html]

Чехов 1892: А. П. Чехов, Палата № 6, [https://ilibrary.ru/text/989/p.19/ index.html]

Чехов 1893: А. П. Чехов, Черный монах, [https://ilibrary.ru/ text/985/p.9/index.html]

Чехов 1895: А. П. Чехов, Чайка, [https://ilibrary.ru/text/971/p.4/index.html] Чехов 1897: А. П. Чехов, Мужики, [https://ilibrary.ru/text/1160/p.8/ index.html]

Чехов 1898а: А. П. Чехов, Человек в футляре, [https://ilibrary.ru/ text/438/p.1/index.html]

Чехов 1898б: А.П.Чехов, Крыжовник, [https://ilibrary.ru/text/460/p.1/ index.html]

Чехов 1899-1902: А. П. Чехов, Архиерей, [https://ilibrary.ru/ text/1185/p.4/index.html]

Чехов 1900: А. П. Чехов, Три сестры, [https://ilibrary.ru/text/973/p.4/ index.html]

Чехов 1902-1903: А. П. Чехов, Невеста, https://ilibrary.ru/ text/1184/p.6/index.html

Чехов 1970а: А. П. Чехов, Собрание сочинений в восьми томах: том 2. Москва: Издательство „Правда”.

Чехов 1970б: А. П. Чехов, Собрание сочинений в восьми томах: том 3. Москва: Издательство „Правда”. 
Чехов 1970в: А. П. Чехов, Собрание сочинений в восьми томах: том 4. Москва: Издательство „Правда”.

Чехов 2013а: А. П. Чехов, Изабрана дела I. Сремски Карловци, Нови Сад: Издавачка књижарница Зорана Стојановића.

Чехов 2013б: А. П. Чехов, Изабрана дела II. Сремски Карловци, Нови Сад: Издавачка књижарница Зорана Стојановића.

\section{Референце}

Остин 1994: Џ. Л. Остин, Како деловати речима: предавања на Харварду 1955. године. Нови Сад: Матица српска.

Пипер 2014:П.Пипер, Лингвистичка славистика. Београд: Славистичко друштво Србије.

Пипер и сарадници 2005: П. Пипер, И. Антонић, В. Ружић, С. Танасић, Љ. Поповић, Б. Тошовић, Синтакса савременог српског језика: проста реченища. Београд: Институт за српски језик САНУ, Београдска књига, Матица српска. 


\title{
Олга Стоядинович
}

\section{ПОСЛЕДНИЕ СЛОВА ЛИТЕРАТУРНЫХ ПЕРСОНАЖЕЙ (НА МАТЕРИАЛЕ ПРОИЗВЕДЕНИЙ АНТОНА ПАВЛОВИЧА ЧЕХОВА)}

\begin{abstract}
Резюме
В статье рассматриваются последние слова литературных персонажей с целью их прагматического анализа, основанного на теории речевых актов. Материалом для исследования стали сочинения Антона Павловича Чехова. В проанализированных примерах предсмертных слов литературных героев преобладают речевые акты директивного и экспрессивного типов, в то время как высказывания с ассертивной и декларативной функциями реже употребляются. С другой стороны, из-за уникальности речевой ситуации, комиссивы полностью отсутствуют.
\end{abstract}

Ключевые слова: последние слова литературных героев, Антон Павлович Чехов, русская литература, речевые акты. 